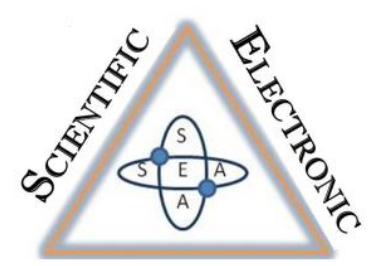

ArChives

Scientific Electronic Archives |Volume 5 |p. 1- 4|2014

\title{
New geographical distribution and seasonality of Costalimaita ferruginea (Coleoptera: Chrysomelidae) on Eucalyptus urograndis in Guiricema, Minas Gerais, Brazil
}

\author{
E. M. Pires ${ }^{+}$, J. N. Corassa', R. M. Nogueira', M. A. Oliveira² , C. L. M. Manica', J. A. M. \\ Ferreira ${ }^{2}$, M. A. Soares 3 \\ 1 Universidade Federal de Mato Grosso, Campus Sinop, Mato Grosso, Brasil. \\ 2 Universidade Federal de Viçosa, Minas Gerais, Brasil. \\ 3 Universidade Federal dos Vales do Jequitinhonha e Mucuri, Minas Gerais, Brasil.
}

+ Author for correspondence: evaldo.pires@gmail.com

\begin{abstract}
Costalimaita ferruginea (Fabricius) (Coleoptera: Chrysomelidae) is a voracious defoliator, responsible for big losses associated to eucalyptus plantations. The attack of this pest can be characterized by the appearance of holes in the leaves and consequent fall, which reduces the photosynthetic potential, and thus slows the development of plants attacked. The objective of this research was to report the new occurrence and characterize the period of attack of beetle C. ferruginea in plantations of hybrid Eucalyptus grandis $x$ Eucalyptus urophylla (= Eucalyptus urograndis) (Myrtaceae) in municipality of Guiricema, Minas Gerais State, Brazil. The period of monitoring started in December 2006 and extended until December 2012. The first attacks of C. ferruginea in this region started in the end of September, and showed a peak of population and greater intensity of damage from mid-October until the second week of November.

Key-words: Attack, damage, populational peak, "Zona da Mata"
\end{abstract}

\section{Resumo}

Costalimaita ferruginea (Fabricius) (Coleoptera: Chrysomelidae) é um desfolhador voraz responsável por grandes perdas associada a plantios de eucalipto. O ataque dessa praga pode ser caracterizado pelo aparecimento de furos nas folhas e conseqüente queda, o que reduz o potencial fotossintetizante, e com isso, retarda o desenvolvimento das plantas atacadas. 0 objetivo desta pesquisa foi relatar a nova ocorrência e caracterizar o período de ataque do besouro C. ferruginea em plantios do híbrido Eucalyptus grandis x Eucalyptus urophylla (= Eucalyptus urograndis) (Myrtaceae) no município de Guiricema, Minas Gerais, Brasil. O período de monitoramento iniciou em dezembro de 2006 e estendido até dezembro 2012. Os primeiros ataques de C. ferruginea nessa região iniciaram no final de setembro, e apresentou pico populacional e maior intensidade de danos de meados de outubro até a segunda semana de novembro.

Palavras-chaves: Ataque; danos; pico populacional, Zona da Mata 


\section{Contextualization}

Guiricema is located in the "Zona da Mata Mineira" and its main activities is the familiar agriculture, beyond the provision wood for furniture industries in the municipalities of "Visconde do Rio Branco" and "Uba", two of major centres of this activity in Brazil.

Recently, the use of eucalyptus forests has become a good investment in Guiricema, since the entire production of wood can be used to supply the demand regional.

Costalimaita ferruginea (Fabricius, 1801) (Coleoptera: Chrysomelidae) is considered one of the major defoliating pests of eucalyptus in Brazil due its voracity and biotic potential (Santos et al., 2009; ZANUNCIO et al., 1993). This species is popularly known as "vaquinha" or "besouro amarelo do eucalipto" and its occurrence has been reported in the States of Rio Grande do Norte, Pará, Maranhão, Bahia, Goiás, São Paulo (Mendes, 2004; Pinto et al., 2004), Roraima (Marsaro Jr., 2006), Mato Grosso do Sul (Berti -Filho et al., 1980;
Kassab et al., 2011), Paraná, Rio Grande do Sul (Santos et al., 2009), Espírito Santo (Souza et al., 2010) and Mato Grosso (Pires et al., 2012). In addition to these reports, the "Padre Jesus Santiago Moure" entomological collection from the Department of Zoology of the Federal University of Paraná (DZUP) possess some specimens collected in Ceará and Pernambuco States (Prof. H. Germano Rosado Neto - UFPR - personal information). Individuals of Costalimaita sp. were found in eucalyptus plantations from Minas Gerais State (Freitas et al., 2002) causing outbreaks in the Zona da Mata (Santos et al., 2009). Reports are more common in the savannah regions, where these adult insects migrate from native plants to young eucalyptus plantations.

Only adults of this beetle species are defoliators and attack and damage eucalyptus plants with any age (Mendes et al., 1998), reducing the growth and even killing the trees.

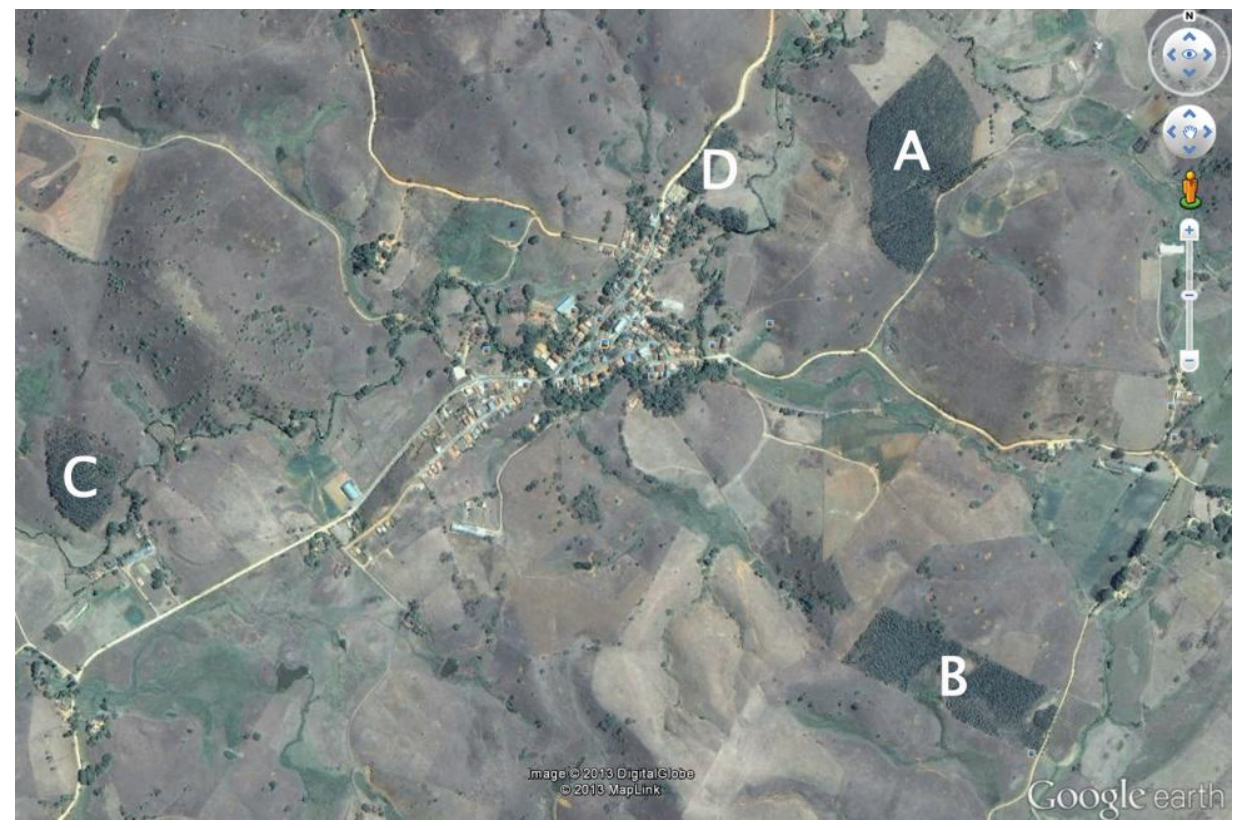

Source: Google Earth

Figure 1. Top view of eucalyptus plantations located in municipality of Guiricema, Minas Gerais State, Brazil, and details with enhance to plantations of Eucalyptus urograndis in the Farms: Caneca - Plots 1 (A) e 2 (B), Recreio II (C) and Boa Vista (D). 

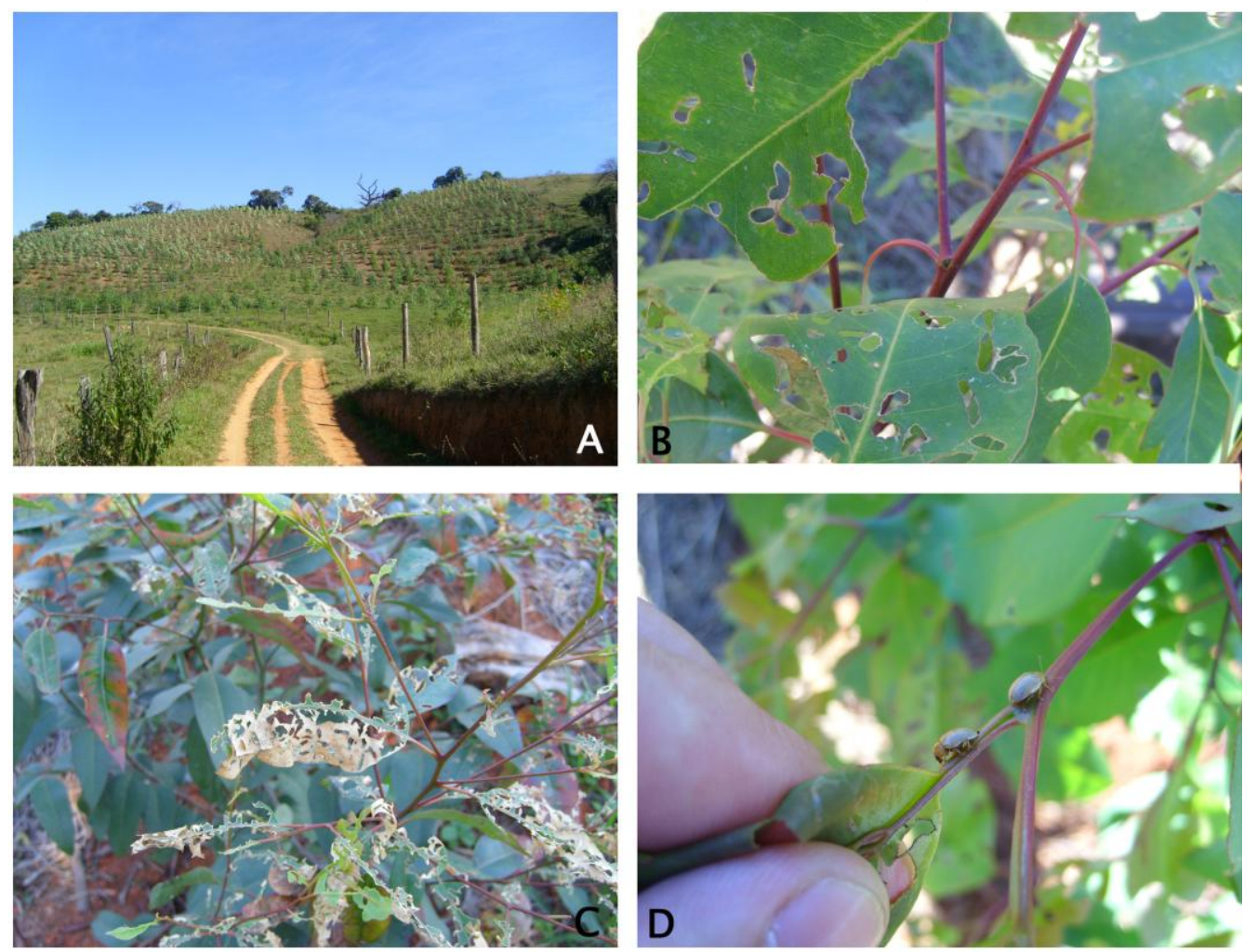

Figure 2. (A) Plantations of Eucalyptus urograndis attaked by Costalimaita ferruginea (Coleoptera: Chrysomelidae) in municipality of Guiricema, Minas Gerais State. (B and C) Damage causing by adults of C. ferruginea in young plants of E. urograndis. (D) Specimes of C. ferruginea in $E$. urograndis plants.

This species is characterized by small body size (5-6 mm long), yellowish-brown colour and bright orange ventral region, elytra with 15-18 longitudinal carena and small circular spots on the leading edge of the wing. They feed mainly on young leaves located in the upper third part of the tree canopy. But they can attack the entire canopy when there are outbreaks and produce holes on the leaves, a characteristic damage of Coleoptera defoliators (Santos et al., 2009). The immature develops below ground and feeds on grasses roots. The aim of this study was to report a new occurrence and characterize the period of attack of the beetle $C$. ferruginea in plantations of the hybrid Eucalyptus grandis $x$ Eucalyptus urophylla (= Eucalyptus urograndis) (Myrtaceae) in the municipality of Guiricema, Minas Gerais State (Brazil), between 2006 and 2012 .

Adults of $C$. ferruginea were observed feeding on young plants of $E$. urograndis (six months till six years of age) in four areas with E. urograndis. These areas are located in Farm Caneca - Plot 1 ( S 20 57' 48.84", W 42 ${ }^{\circ} 39^{\prime}$ 29.79") with three hectares of total area (Figure 1), Plot 2 (S $20^{\circ} 58^{\prime}$ 22.76", W $\left.42^{\circ} 39^{\prime} 26.06^{\prime \prime}\right)$ with six hectares of total area (Figure $1 \mathrm{~B}$ ), Farm

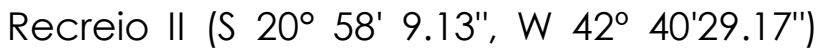
with two hectares of total area (Figure $1 \mathrm{C}$ ) and Farm Boa Vista (S $20^{\circ} 57^{\prime} 48.69^{\prime \prime}$, W $42^{\circ}$ $\left.39^{\prime} 44.75^{\prime \prime}\right)$ with four hectares of total area (Figure $1 \mathrm{D})$.

The first attacks of $C$. ferruginea on eucalyptus in this region started at the end of September, when few individuals were observed. Between the second and third week of October to mid-November represents the period preceding the rainy period and the occurrence of damage and the beetle population were higher. The attack was observed mainly on young leaves at the ends of apical and lateral branches (Figure 2A, B, C and D), with higher intensity in the early morning and late afternoon. The insects remained with no activity on the underside of the leaves 
during the warmest period of the day. They used to disperse rapidly when a person walked close to the plant, a typical behaviour of Chrysomelidae.

Besides the monitored sites, information provided by EMATER office indicated that this beetle occurs in all fields of the Guiricema.

\section{Acknowledgments}

We are grateful to Maria José Ferreira de Souza and José Braz Martins dos Santos from Vilas Boas, municipality of Guiricema, Minas Gerais State for the technical assistance.

\section{References}

BERTI FILHO, E., MENDES-FILHO, J.M.A., KRÜGNER, T.L. Pragas e doenças de Eucalyptus na região do Mato Grosso do SUl. IPEF. Circular Técnica, 106, p. 1-12. 1980.

FREITAS, F.A., Zanuncio, T.V., Lacerda, M.C., Zanuncio, J.C. Fauna de Coleoptera coletada com armadilhas luminosas em plantios de Eucalyptus grandis em Santa Bárbara, Minas Gerais. Revista Árvore 26: 505-511. 2002.

KASSAB, S.O., MOTA, T.A., PEREIRA, F.F., FONSECA, P.R.B. Primeiro relato de Costalimaita ferruginea (Fabricius, 1801) (Coleoptera: Chrysomelidae) em eucalipto no Estado do Mato Grosso do Sul. Ciência Florestal 21: 777-780. 2011.

MARSARO JÚNIOR, A.L. Levantamento de pragas em plantios de Acacia mangium em Roraima. 2006. http://www.agronline.com.br/artigos/artigo .php?id =303

MENDES, J.E.P. Efeitos do ataque de Costalimaita ferruginea (Fabr.) (Coleoptera: Chrysomelidae) sobre crescimento e produção de Eucalyptus grandis (Hill ex Maiden). 61f. (Tese de Doutorado) Universidade Federal de Viçosa, Viçosa, Brasil, 2004.

MENDES, J.E.P., ANJOS, N., CAMARGO, F.R.A. Monitoramento do besouro-amarelo.

Folha Florestal 91: 8-9. 1998.
PINTO, R., ZANUNCIO JUNIOR, J.S., ZANUNCIO, T.V., ZANUNCIO, J.C., LACERDA, M.C. Coleopteros coletados com armadilhas luminosas em plantio de Eucalyptus urophylla na Região Amazônica Brasileira. Ciência Florestal 14: 111-119. 2004.

PIRES, E.M., CORASSA, J.N., BARRETO, M.R., SOARES, M.A. New Report of Costalimaita ferruginea (Fabricius) (Coleoptera: Chrysomelidae) on Eucalyptus sp. (Myrtaceae) in Sinop - Mato Grosso, Brazil. EntomoBrasilis 6: 89-90. 2013.

SANTOS, G.P., ZANUNCIO, J.C., ZANUNCIO, T.V., PIRES, E.M. Pragas do Eucalipto. Informe Agropecuário 29: 43-64. 2009.

SOUZA, R.M., ANJOS, N., MAFIA, R.G. Novos locais de ocorrência de Costalimaita ferruginea no Estado do Espírito Santo. In: XXIII Congresso Brasileiro de Entomologia. Natal, RN. p. 1318. 2010.

ZANUNCIO, J.C., BRAGANÇA, M.A.L., LARANJEIRO, A.L., FAGUNDES, $M$. Coleópteros associados à eucaliptocultura nas regiões de São Mateus e Aracruz, Espírito Santo. Revista Ceres 41: 584-590. 1993. 